\title{
How Contract Farming in Poultry Industry Contribute to the Sustainable Community Economic Development of Bangladesh: A Literature Review
}

D.O.I - 10.51201/Jusst12585

http://doi.org/10.51201/Jusst12585

\author{
${ }^{1}$ Mohamed K Haq \\ M.Com., PGDPM, M.Sc. (LSE, UK)
}

Ph.D. Student in Management, Limkokwing University of Creative Technology, Malaysia Former Lecturer, Department of Management, University of Dhaka, Bangladesh Freelance Trainer in Industrial and Management Training Freelance Human Resources Management Consultant

\section{${ }^{2}$ Saleh Md Arman}

MSc in Sustainable Development, Uppsala University. BBA, MBA (Dhaka University).

Assistant Professor(on leave), RP Shaha University, Bangladesh Researcher in Circular Economy and Community Economic Development.

\section{${ }^{3}$ Farzana Nazera}

MBA (Bangladesh), MBA (Malaysia)

Ph.D. Student in Management, Limkokwing University of Creative Technology, Malaysia

\begin{abstract}
In agricultural production, contract farming is a widely recognized strategy all over the world where similar type of farmers from different corners of a country are engaging under a single industry. In poultry industry of Bangladesh, Contract Farming (CF) is quite popular. Since inception in 1994, contract farming in poultry industry is quite common and major industrial players of Bangladesh deploy this strategy for gaining competitive advantage. In the CF model, the contribution of an individual farmer to the gigantic production volume of a large poultry farm can't be denied and, in this way, CF can play a vital role in the sustainable community economic development. The objective of the study is to assess how Contract Farming can contribute in the sustainable community economic development of Bangladesh in the light ofSustainable Development Goals. The study is literature review in nature and secondary sources of information has been consulted. The study concluded that, contract farming is crucial in poultry industry and its contribution in assuring sustainable community economic development is significant.
\end{abstract}

Keywords: Contract Farming (CF), Community Economic Development (CED), Sustainable Development. 


\section{Introduction and Problem Statement}

In order to achieve the sustainable development goals within 2030, Bangladesh strives to comply with as many goals as possible within the timeframe. One of the highly density countries of the world, it is always challenging for Bangladesh to ensure the reduction of poverty (SDG 1), hunger problem (SDG 2), gender equality (SDG 5), unemployment problem (SDG 8) and the country'slivestock production is the key in this aspect (Meemken and Bellemare, 2020; Smith et al., 2013; Alary, Corniaux and Gautier, 2011; Begum et al., 2007; Setboonsarng, Leung and Cai, 2006; Upton, 2004; Perry, 2002; Jensen, 1999; Glover et al., 1990). In 2017-18, the GDP contribution by Livestock production was $1.54 \%$ and in the same year the growth rate in Livestock production was 3.40\% (DLS, 2018). In 2017-18, the total Livestock production was 3937.37 lakh and out of them, the poultry production was 3379.98 lakh (ibid). The direct employment generated by the poultry industry alone was $20 \%$ (ibid). From this statistic, it has been seen that, Poultry industry is viable for the development of the country at large which ensures the sustainable development journey efficiently and effectively through community economic development. Large poultry farms of Bangladesh strive to develop communities of poultry producers in both economic and community development which is essential in attaining sustainable development ((Meemken and Bellemare, 2020; Shaffer, Deller and Marcouiller, 2006; Audirac, 1997).

In many countries of the world, Contract Farming (CF) has been firstly initiated by the government (Gatto et al., 2017; Larson and World Bank, 1996), however, in Bangladesh it was not happen.The journey of contract farming has been initiated by the private sector and first of all the most popular strategy has been taken by the large business enterprises since 1994 through the inception by the Aftab Bohumukhi Farms Limited (ABFL) (Begum et al., 2012). After ABFLs application to this strategy in the remote corners of the country, other local enterprises join in the journey to exploit the competitive advantage of available resources. Many small-scale poultry producers from different areas of Bangladesh are engaging in this industry through these enterprises. Hence, there is a positive impact on the overall community economic development of the remote areas through employment generation, alleviate poverty and resolve hunger problem. The study would like to see the role of Poultry industry contract farming in community economic development through intervening in four sustainable development goals that are closely associated with it which are:poverty alleviation, hunger problem solution, gender equality and employment generation.

\subsection{Research Gap and Originality of the study:}

This paper discussed how the contract farming of poultry industry ensure sustainable community economic development in the light of four sustainable development goals. The study also identifies what targets of each goal is satisfied by the contract farming of poultry industry to create sustainable community economic development. This is a new exploration of this area and the study would like to work on it by conducting this literature review.

\section{Aim and Objectives}

The study aims to see how contract farming of Bangladesh could be related in community economic development by interacting SDG 1, SDG 2, SDG 5 and SDG 8. The objectives of this study are as follows:

1. To review the literatures of contract farming concept in Bangladesh perspectives.

2. To review the literature of community economic development in Bangladesh perspectives.

3. How contract farming in poultry industry contribute to the community economic development in the light of sustainable development goals. 
In this aspect, the study considers the secondary sources of literature.

\subsection{Scope and delimitation:}

Contract farming is a widespread practice in the poultry industry of Bangladesh (Begum et al., 2013; 2012; Jabbar et al., 2007; Begum, 2008; 2005) and the study would consider the contact farming scenario of Bangladesh. From reviewing the literatures, the study would limit to find out the contribution of contact farming in the community economic development in the light of four sustainable development goals those the study considered vital and those goals are closely interact with contact farming (Griggs et al., 2017) of poultry industry.

\subsection{Ethical Consideration}

In order to ensure the authenticity of the source, the study has only considered the scholarly articles and trusted websites of governments and regulatory agencies.

\section{Concept of Contract Farming:}

Contract Farming (CF) practices has existed for a long time, especially for perishable agricultural products for example, milk, fruits and vegetables (Bijman, 2008; Shepherd, 2005; Eaton and Shepherd, 2001; Little and Watts, 1994). At the end of $20^{\text {th }}$ century, contract farming practices has been popular in agriculture sectors due to changes in international competition, consumer demands, technological revolution in developed and developing countries which made the agricultural systems more organized and closely managed (Prowse, 2012; Bijman, 2008;Swinnen and Maertens, 2007; Minot, 2007; 1986; Shepherd, 2005; Dannson, 2004;Reardon and Berdegué, 2002; Reardon and Barrett, 2000; Royer and Rogers, 1998; Martinez and Reed, 1996; Little and Watts, 1994). The study has considered the following definitions of Contract Farming which mentioned different characteristics of this concept which are the keys to understand this concept in details:

Table 1: Contract farming definition and underlined characteristics:

\begin{tabular}{|c|c|c|}
\hline Scholars & Definitions & Underlined Characteristics \\
\hline $\begin{array}{l}\text { Mighell and Jones } \\
\text { (1963) }\end{array}$ & $\begin{array}{l}\text { Contract farming is a vertically integrated } \\
\text { agricultural contract between a business } \\
\text { farm and a farmer (or farmers) which } \\
\text { guarantee a farmer a marketing outlet and } \\
\text { time of sale, and possibly a price structure, } \\
\text { if some degree of quality is met. }\end{array}$ & $\begin{array}{l}\text { 1) Vertical integration } \\
\text { 2)Guarantee between two } \\
\text { parties } \\
\text { 3)Price structure }\end{array}$ \\
\hline Roy $(1963 ; 1972)$ & $\begin{array}{l}\text { Contract Farming is contractual } \\
\text { arrangements between farmers and other } \\
\text { firms, whether oral or written, specifying } \\
\text { one or more conditions of production } \\
\text { and/or marketing of an agricultural product. }\end{array}$ & $\begin{array}{l}\text { 1)Oral and/ or written contract, } \\
\text { 2)conditions of production and } \\
\text { marketing }\end{array}$ \\
\hline $\begin{array}{l}\text { Glover (1984; 1986; } \\
\text { 1987) } \\
\text { Glover and Kusterer } \\
(1990)\end{array}$ & $\begin{array}{l}\text { Contract farming is a private sector scheme } \\
\text { where the large firm replaces or } \\
\text { supplements company production of } \\
\text { agricultural commodities with purchases } \\
\text { from local farmers through contracts } \\
\text { specifying sales conditions and aiming to } \\
\text { provide technical assistance, agro- }\end{array}$ & $\begin{array}{l}\text { 1)Private sector centric, } \\
\text { 2)Sales and exchange } \\
\text { conditions, }\end{array}$ \\
\hline
\end{tabular}




\begin{tabular}{|c|c|c|}
\hline & chemicals and other services. & \\
\hline Minot $(1986 ; 2007)$ & $\begin{array}{l}\text { Contract Farming is an agricultural } \\
\text { production which is being carried out } \\
\text { according to a prior agreement in which the } \\
\text { farmer commits to producing a given } \\
\text { product in a given manner and the } \\
\text { buyercommits to purchasing it. }\end{array}$ & $\begin{array}{l}\text { 1) Agreement based production } \\
\text { 2) Mutual commitment. }\end{array}$ \\
\hline $\begin{array}{l}\text { Catelo, Dorado, and } \\
\text { Agbisit, Jr. (2001), } \\
\text { Catelo (2002) and } \\
\text { Catelo and Costales } \\
(2008)\end{array}$ & $\begin{array}{l}\text { Contract Farming is a binding arrangement } \\
\text { between a firm (contractor) and an } \\
\text { individual producer (contractee) in the } \\
\text { form of a 'forward agreement' with well- } \\
\text { defined obligations and remuneration for } \\
\text { tasks done, often with specifications on } \\
\text { product } \\
\text { such as volume, quality, and timing of } \\
\text { delivery }\end{array}$ & $\begin{array}{l}\text { 1)The two parties "Contractor" } \\
\text { and "Contractee" involve in a } \\
\text { forward agreement. } \\
\text { 2)Remuneration. } \\
\text { 3) Specific Volume, quantity } \\
\text { and delivery timing }\end{array}$ \\
\hline $\begin{array}{l}\text { Costales } \\
(1996 ; 2000 ; 2001) \\
\text { Costales and Delgado } \\
(2002), \\
\text { Catelo and Costales } \\
(2008)\end{array}$ & $\begin{array}{l}\text { Contract farming is a contract between a } \\
\text { contractor and a contractee in a legalized } \\
\text { contract of livestock productions of } \\
\text { smallholder farms in order to achieve } \\
\text { sustainable development through food } \\
\text { security. }\end{array}$ & $\begin{array}{l}\text { 1)Livestock production } \\
\text { 2)Food security } \\
\text { 3)Sustainable development }\end{array}$ \\
\hline $\begin{array}{l}\text { Eaton and Shepherd, } \\
(2001)\end{array}$ & $\begin{array}{l}\text { Contract farming can be defined as an } \\
\text { agreement between farmers and processing } \\
\text { and/or marketing firms for the production } \\
\text { and supply of agricultural products under } \\
\text { forward agreements, frequently at } \\
\text { predetermined prices. }\end{array}$ & $\begin{array}{l}\text { 1)Market Provision } \\
\text { 2)Resource Provision } \\
\text { 3)Management Specification }\end{array}$ \\
\hline Singh (2002) & $\begin{array}{l}\text { Contract Farming follows the typology: (a) } \\
\text { procurement contracts under which only } \\
\text { purchase conditions are specified; (b) } \\
\text { partial contracts wherein only some of the } \\
\text { inputs are supplied by the contractor and } \\
\text { produce is bought at pre-agreed prices; and } \\
\text { (c) total contracts under which the } \\
\text { contractor supplies and manages all the } \\
\text { inputs of the farm and the farmer becomes } \\
\text { just a supplier of land and labour. }\end{array}$ & $\begin{array}{l}\text { Contract Farming typology: } \\
\text { procurement contract, partial } \\
\text { contract and total contract }\end{array}$ \\
\hline $\begin{array}{l}\text { Simmons (2002) } \\
\text { Simmons, Winter and } \\
\text { Patrick (2005) }\end{array}$ & $\begin{array}{l}\text { Contract farming usually involves a large } \\
\text { agribusiness firm integrating backwards by } \\
\text { forming alliances with groups of } \\
\text { smallholders and, through written or verbal } \\
\text { contracts, providing farm inputs such as } \\
\text { credit and extension in return for } \\
\text { guaranteed delivery of produce of specified } \\
\text { quality often at a pre-determined price. CF } \\
\text { also involve horizontal integration where } \\
\text { firms not only provide direct inputs into } \\
\text { farm-level decision making but also } \\
\text { encourage integration of various activities }\end{array}$ & $\begin{array}{l}\text { 1)Backward linkage } \\
\text { 2) written or verbal contracts } \\
\text { 3) providing farm inputs } \\
\text { 4) guarantee of product delivery } \\
\text { with specified quality and price. } \\
\text { 5) Horizontal Integration. }\end{array}$ \\
\hline
\end{tabular}




\begin{tabular}{|c|c|c|}
\hline & $\begin{array}{l}\text { across a population of smallholders through } \\
\text { farm groups. }\end{array}$ & \\
\hline Da Silva (2005) & $\begin{array}{l}\text { Contract Farming is an intermediate mode } \\
\text { of coordination, whereby the conditions of } \\
\text { exchange are specifically set among } \\
\text { transaction partners by some form of } \\
\text { legally enforceable, binding agreement. } \\
\text { The specifications can be more or less } \\
\text { detailed, covering provisions regarding } \\
\text { production technology, price discovery, } \\
\text { risk-sharing and other product and } \\
\text { transaction attributes }\end{array}$ & $\begin{array}{l}\text { 1)Legal forms } \\
\text { 2) Specific exchange conditions }\end{array}$ \\
\hline Rehber (2007) & $\begin{array}{l}\text { Contract Farming is a contractual } \\
\text { arrangement between farmers and other } \\
\text { firms, whether oral or written, specifying } \\
\text { one or more conditions of production, and } \\
\text { one or more conditions of marketing, for an } \\
\text { agricultural product, which is non- } \\
\text { transferable. }\end{array}$ & $\begin{array}{l}\text { 1) Oral or written agreement } \\
\text { 2)Specific production and } \\
\text { marketing conditions } \\
\text { 3)Non transferable contract }\end{array}$ \\
\hline Hamilton (2008) & $\begin{array}{l}\text { Contract Farming is an agricultural } \\
\text { production contract is a legally binding } \\
\text { agreement of a fixed term, entered before } \\
\text { production begins, under which a producer, } \\
\text { either agrees to sell or deliver all of a } \\
\text { specifically designated crop raised on } \\
\text { identified acres in a manner set in the } \\
\text { agreement, to the contractor, and is paid } \\
\text { according to a price or payment method, } \\
\text { and at a time, determined in advance; or } \\
\text { agrees to feed and care for livestock or } \\
\text { poultry owned by the contractor until such } \\
\text { time as the animals are removed, in } \\
\text { exchange for a payment based on the } \\
\text { performance of the animals. Under the } \\
\text { agreement, the producer may have no legal } \\
\text { title to the crop or livestock but is a bailee, } \\
\text { and the producer is declared to be an } \\
\text { independent contractor and not an } \\
\text { employee or joint venturer with the } \\
\text { contractor. }\end{array}$ & $\begin{array}{l}\text { 1) A legally binding agreement } \\
\text { between the producer and } \\
\text { contractor; } \\
\text { 2) The agreement is for a fixed } \\
\text { term; } \\
\text { 3) The agreement is signed or } \\
\text { entered into before production } \\
\text { begins; } \\
\text { 4) The contract calls for either } \\
\text { the crop or animal production } \\
\text { 5) The crops or livestock will be } \\
\text { delivered or sold to the } \\
\text { contractor } \\
\text { 6) The crops or livestock must } \\
\text { be produced or cared for } \\
\text { according to the terms of the } \\
\text { agreement, to be acceptable; } \\
\text { 7) The producer will be paid an } \\
\text { amount and may include } \\
\text { premiums or deductions for } \\
\text { quality or performance. } \\
\text { 8) The producer generally has } \\
\text { no legal title to the crop or } \\
\text { livestock. } \\
\text { 9) The producer is described as } \\
\text { an independent contractor. }\end{array}$ \\
\hline Bijman (2008) & $\begin{array}{l}\text { Contract farming agreements should have } \\
\text { the following } 12 \text { provisions:1) the duration } \\
\text { of the contract 2) the quality standards to } \\
\text { be applied 3) quality control (when, how, } \\
\text { who is responsible, who pays) 4)the }\end{array}$ & $\begin{array}{l}\text { Twelve provisions of Contract } \\
\text { Farming Agreements. }\end{array}$ \\
\hline
\end{tabular}




\begin{tabular}{|c|c|c|}
\hline & $\begin{array}{l}\text { quantity that the farmer is obliged or } \\
\text { allowed to deliver 5) the cultivation / } \\
\text { raising practices required by the contractor } \\
\text { 6) the timing of delivery 7) packaging, } \\
\text { transport and other delivery conditions 8) } \\
\text { price or price determination mechanism } \\
\text { (such as fixed prices, flexible prices based } \\
\text { on particular (spot) markets, consignment } \\
\text { prices, or split prices) 9) technical } \\
\text { assistance 10) procedures for paying } \\
\text { farmers and reclaiming credit advances 11) } \\
\text { insurance 12) procedures for dispute } \\
\text { resolution }\end{array}$ & \\
\hline Prowse (2012) & $\begin{array}{l}\text { Contract Farming is a contractual } \\
\text { arrangement for a fixed term between a } \\
\text { farmer and a firm, agreed } \\
\text { verbally or in writing before production } \\
\text { begins, which provides resources to the } \\
\text { farmer and/or specifies one or more } \\
\text { conditions of production, in addition to one } \\
\text { or more marketing conditions, for } \\
\text { agricultural production on land owned or } \\
\text { controlled by the farmer, which is non- } \\
\text { transferable and gives the firm, not the } \\
\text { farmer, exclusive rights and legal title to } \\
\text { the crop. }\end{array}$ & $\begin{array}{l}\text { 1)Fixed term contract } \\
\text { 2)Written or verbal } \\
\text { 3)Specific production and } \\
\text { marketing condition } \\
\text { 4)Non-transferable, } \\
\text { 5)Firm has got the right and } \\
\text { legal title to the crop. }\end{array}$ \\
\hline Barrett et al. (2012) & $\begin{array}{l}\text { The contract farming arrangement (CFAs) } \\
\text { between smallholders and a modern } \\
\text { agribusiness firm has four stages including } \\
\text { the prominence of geographic supply chain } \\
\text { placement and farmer selection effects, the } \\
\text { heterogeneity of contractual arrangements } \\
\text { and contract terms, the prospective roles of } \\
\text { farmer groups and cooperatives as } \\
\text { contracting agents, and the highly variable } \\
\text { (albeit typically positive) average returns to } \\
\text { farmers from value chain participation. }\end{array}$ & $\begin{array}{l}\text { Four stages of Contract farming } \\
\text { arrangement (CFAs) }\end{array}$ \\
\hline
\end{tabular}

From the scholarly definitions mentioned in the table above, the study can said that, Contact Farming is an oral or written nontransferable legal agreement between a business firm (contractor) and a farmer/producer or a group of farmers/ producers (contractee) where each terms and conditions, ranging from production to the delivery of contractor's premise, should be clearly specified and both parties are committed to carry out the contract with utmost professional and mutual manner.

\subsection{Contract Farming in Bangladesh}

Developing countries, like Bangladesh, Contract Farming gains popularity inthe following reasons: a) reduced risks in production and marketing of crops and livestock, (b) improved access to inputs, technical assistance and credit, c) Less effect on overall supply in the event of crop failure of one or few farmers; d) More flexible production portfolio of smallholders, which would help in quickly responding to 
consumers' changing preferences; e) Smallholders could ensure better quality as they strictly comply with the production practices advised by the firm mainly due to more family labor and lower bargaining power; and f) Low marketable surplus of smallholders increase their dependency on the firm for profit maximization (Bijman, 2008;Pomareda, 2006;Birthal et al., 2005; Guo et al. 2005; Masakure and Henson 2005; Singh, 2002; Simmons, 2002; Eaton and Shepherd, 2001; Runsten and Key, 1996).

In Bangladesh, contract farming is popular in Poultry industry (Begum et al., 2013; 2012;Jabbar et al., 2007; Begum, 2008; 2005), however, some other specific livestock and agricultural products are also engaging, like: Rice (Islam et al., 2020;Roy et al., 2013; Balcombe et al., 2007); Vegetables (Wadud et al., 2015)Mashroom (Zamil and Cadilhon, 2009), Beef Cattle (Sarma, 2014), Dairy (Saiful et al., 2019), Maize (Adnan et al., 2018; Haque et al., 2012), Tomato seed production (Sarkar, Rashid and Sarker, 2013), Potato Seed Production (Tabassum and Kim, 2009), Flower (Mou, 2012) and Tobacco (Hussain et al., 2020).Moreover, Bangladeshi organic shops namely: Probortana, PROSHIKA, and Meena Baza are using contract farming which is a good example of green movement and sustainable agriculture to achieve sustainable development for the country (Ferdous et al., 2020; Hoque, 2012; Hossain, 2012).

\subsection{Contract Farming in the Poultry Industry of Bangladesh:}

From the research contributions of several researchers (Islam et al., 2014; Sheel and Sen, 2013; Begum et al., 2013; 2012; 2005; Jabbar et al., 2007; Begum, 2008; 2005; Aziz and Miah, 2005) it is evident that, contract farming is the most usable terms of agreement in poultry sector compared to other forms of producing foods. They said that, contract farming was introduced in 1994 by Aftab Bohumukhi (multipurpose) Farms Limited (ABFL) and they have been leading the poultry industry since then (ibid). According to Begum et al. (2013;2012;2005), contract farmers of Bangladesh are classified into three categories as per ABFL's framework: (1) small farmers raising 1200 birds, (2) medium farmers raising 1201 up to 2000 birds, (3) large farmers raising more than 2000 birds and up to 2011, there were 202 small, 280 medium and 78 large farms were working as contractees of ABFL.

In Bangladesh, there are three types of Contract Farming practices in Bangladesh namely: 1) formal production marketing contract, 2) formal input-marketing contract and 3) Informal Output-marketing contract (Sheel and Sen, 2013; Jabbar et al., 2007). In formal production marketing contract, the contracting agreements are written and the documents are signed by the parties involved within a vertically integrated enterprise for supply of inputs and services, sell outputs, and share risks and benefits (ibid). The main actors in this arrangement in Bangladesh are Aftab BAHUMUKHI Farms Ltd (ABFL) in Kishoregonj district, Biman Poultry Complex in Savar near Dhaka district and BRAC's poultry operations in a number of districts in Bangladesh (ibid). In formal input-marketing contracts, the agreement is documented in writing and signed by the parties concerned and the contract should mention about the supply of one or more inputs and services, generally to market agents who directly deal with producers (ibid). In Bangladesh, Kazi farms Ltd., Paragon Poultry Ltd., and Nourish Poultry \& Hatchery Ltd practice formal input marketing contracts (ibid). The last type is Informal Output-marketing Contracts, which is primarily a forward-purchase contract in which contractors purchase output from existing producers or contractees and the agreement has mostly been done in verbal form or in a form that may not be considered acceptable in a formal court for dispute settlement (ibid). Other than the producers, different categories of middlemen and output retailers are actors in the output marketing chain in this informal output marketing CF system (ibid). The middlemen of eggs in Dhaka city sometimes make forward purchase contracts with layer farmers in Gazipur District and they also sometimes make contracts with agents who then buy eggs from producers with or without prior contract to supply the middlemen (ibid). The important difference between this informal CFA and formal CFA is that these forward contracts are made with existing farms rather than for the establishment of new farms (ibid). 


\section{Contract Farming and Sustainable Community Economic Development in the light of Sustainable Development Goals:}

According toMeemken and Bellemare (2020), Gatto et al. (2017), Bijman (2008),Mendola (2007)Begum et al. (2005), Key and Runsten (1999), contact farming practices in poultry industry play important role in the community development of developing countries in the rural areas in terms of assuring food security, employment generation and family participation in income generation. Contract Farming is an important aspect to ensure sustainable agriculture in terms of the mentioned reasons to develop sustainable community economic development (Bridger and Luloff, 1999; Rogers and Ryan, 2001; Roseland, 2000). In order to develop a sustainable community economic development through promoting contract farming, it is crucial to study the discussion of SDG interactions. These aspects are closely associated with four Sustainable Development Goals which are: SDG 1: No Poverty, SDG 2: Zero Hunger, SDG 5: Gender Equality and SDG: 8: Decent Work and Economic Growth.

Contract farming allows poultry farmers of Bangladesh to earn livelihood essential for survival with family to cover basic needs, enjoy sophisticated technical knowhows, access to the key resources, cooperation with contractors which eventually alleviate them from poverty (Rahman et al., 2020; Islam and Jabbar, 2005; Chowdhury and Bhuiya, 2004; Dolberg, 2003). This support Sustainable Development Goal 1 (SDG 1) by satisfying the following targets (United Nations, 2010):

- $\quad 1.1$ By 2030, eradicate extreme poverty for all people everywhere, currently measured as people living on less than $\$ 1.25$ a day.

- $\quad 1.2$ By 2030, reduce at least by half the proportion of men, women and children of all ages living in poverty in all its dimensions according to national definitions.

- 1.4 By 2030, ensure that all men and women, in particular the poor and the vulnerable, have equal rights to economic resources, as well as access to basic services, ownership and control over land and other forms of 13 property, inheritance, natural resources, appropriate new technology and financial services, including micro-finance.

- 1.6 Ensure significant mobilization of resources from a variety of sources, including through enhanced development cooperation, in order to provide adequate and predictable means for developing countries, in particular least developed countries, to implement programmes and policies to end poverty in all its dimensions.

Contract farming in poultry industry meets the protein demand of the country at a great extent and as per the report published by United States Department of Agriculture (USDA), this sector supplies 36\% of total protein intake of Bangladesh (USDA, 2020). Writings from Rahman et al., (2020), Islam et al., (2014), Sheel and Sen (2013) Begum et al. (2013; 2012), Jabbar et al. (2007), Begum, (2008; 2005), Chowdhury and Bhuiya (2004) found that, contract farming has important contribution in food security of the country through continuous supply of meet and egg, developing infrastructures of sustainable poultry farming, technological access to increase production capacity and real time information about market which are vital for fulfilling sustainable development goals 2: Zero Hunger (SDG2).From the literatures above, the following SDG2 targets have been fulfilled by contract farming of poultry industry in Bangladesh (United Nations, 2010):

- 2.1 By 2030, end hunger and ensure access safe, nutritious and sufficient food all year round.

- $\quad 2.2$ By 2030, end all forms of malnutrition.

- $\quad 2.3$ By 2030, double the agricultural productivity and incomes of small-scale food producers.

- 2.6 Increase investment in rural infrastructure, agricultural research and extension services, technology development and plant and livestock gene banks in order to enhance agricultural productive capacity in developing. 
- 2.7 Adopt measures to ensure the proper functioning of food commodity markets and their derivatives and facilitate timely access to market information, including on food reserves, in order to help limit extreme food price volatility

According to Begum et al., (2019; 2013), Griggs et al. (2017), Anderson and Eswaran (2009), Jabbar et al. (2007) and Islam and Jabbar (2005), contract farming in poultry industry of Bangladesh ensures equal contribution of women which create equal opportunity for women in earning, recognition of contribution, decision making, access to technology, diminishing the chance of discrimination and exploitation and avoidance which leads to fulfill the sustainable development goals 5, i.e., SDG5: Gender Equality. From the literatures discussed, the following targets of SDG5 have been met (United Nations, 2010).

- 5.1 End all forms of discrimination against all women and girls everywhere

- $\quad 5.2$ Eliminate all forms of violence against all women and girls

- $\quad 5.5$ Ensure women's full and effective participation and equal opportunities for leadership at all levels of decision making in political, economic and public life

- $\quad 5.7$ Undertake reforms to give women equal rights to economic resources.

- 5.8 Enhance the use of enabling technology to promote the empowerment of women

- $\quad 5.9$ Adopt and strengthen sound policies and enforceable legislation for the promotion of gender equality and the empowerment of_all women and girls at all levels

According to Begum et al., (2019;2012), Anwar et al. (2017), Sheel and Sen (2013), Jabbar et al, (2007) and Islam and Jabbar (2005), contract farming in Bangladeshi poultry industry ensures economic growth, economic productivity, employment generation of rural people, provide training and development programmes of different sort of farming sophisticated poultry functions and resource efficiency which leads to fulfill a couple of targets of achieving SDG 8: Decent Work and Economic Growth. The following targets of SDG8 have been met:

- 8.1 Sustain per capita economic growth

- $\quad 8.2$ Achieve higher levels of economic productivity

- 8.3 Promote development-oriented policies that support productive activities

- 8.6 Substantially reduce the proportion of youth not in employment, education or training

\section{Conclusion, Limitations of the study and directions for the future research:}

The study only considered the contract farming practices in poultry industry. However, the study mentioned that contract farming is also available in other industries of Bangladesh. The study discussed the existing literatures related to contract farming concept and how it interacts with the sustainable community economic development in the light of sustainable development goals. The study considered four vital goals that found relevant to the existing literatures.

Future research could be a comparative study among different industries' contract farming practices. Also, the study identified that, the published scholarly articles available on reputed journal repositories were only considered ABFL as a contract farming company in the poultry industry of Bangladesh. Future study would cover other poultry giants of Bangladesh like Kazi, Paragon etc. Also, future study would be focused on quantitative studies on developing a model of community economic development which is being enforced by contract farming to achieve sustainable development. 
The study concluded that, similar to many parts of the world, contract farming is vital and popular in Bangladeshi poultry industry and many poultry giants are investing 35000 crores in this industry, making it one of the biggest contributions in the country economy in order to reduce poverty, hunger problem, employment generation and gender equality of ensuring women participation (USDA, 2020). Contract farming in poultry industry is playing diversified role in sustainable community economic development in the light of sustainable development goals. To achieve sustainability as a country, Bangladesh should move forward about contract farming strategy by making it more sustainable, resilient and fruitful.

\section{References}

Adnan, K., Ying, L., Sarker, S., Hafeez, M., Razzaq, A. and Raza, M., 2018. Adoption of Contract Farming and Precautionary Savings to Manage the Catastrophic Risk of Maize Farming: Evidence from Bangladesh. Sustainability, 11(1), p.29.

Audirac, I. (Ed.) (1997). Rural sustainable development in America. New York: John Wiley.

Alary, V., Corniaux, C. and Gautier, D., 2011. Livestock's Contribution to Poverty Alleviation: How to Measure It? World Development, 39(9), pp.1638-1648.

Anderson, S. and Eswaran, M., 2009. What determines female autonomy? Evidence from Bangladesh. Journal of Development Economics, [online] 90(2), pp.179-191. Available at:

<https://www.sciencedirect.com/science/article/abs/pii/S0304387808001089?via\%3Dihub> [Accessed 26 Jan. 2021].

Anwar, M., Ferdous, Z., Sarker, M., Hasan, A., Akhter, M., Zaman, M., Haque, Z. and Ullah, H., 2017. Employment Generation, Increasing Productivity and Improving Food Security through Farming Systems Technologies in the Monga Regions of Bangladesh. Annual Research \& Review in Biology, 16(6), pp.115.

Aziz, M. A. and Miah, M. A. H. (2005) Family poultry farming system in developing countries, a paper presented at the 4th international poultry show and seminar organized by WAPSA, Bangladesh branch, Dhaka.

Balcombe, K., Fraser, I., Rahman, M. and Smith, L., 2007. Examining the technical efficiency of rice producers in Bangladesh. Journal of International Development, 19(1), pp.1-16.

Barrett, C.B., Bachke, M.E., Bellemare, M.F., Michelson, H.C., Narayanan, S. and Walker, T.F., 2012. Smallholder Participation in Contract Farming: Comparative Evidence from Five Countries. World Development, 40(4), pp.715-730.

Begum, A., Osanami, F. and Kondo, T., 2005. Performance of Vertically Integrated Contract and Independent Poultry Farms in Bangladesh: A comparative study. Hokkaido University Collection of Scholarly and Academic Papers : HUSCAP, [online] 61, pp.101-117. Available at: <https://eprints.lib.hokudai.ac.jp/dspace/bitstream/2115/11278/1/61_p101-117.pdf> [Accessed 26 Jan. 2021].

Begum, I., 2005. An Assessment of Vertically Integrated Contract Poultry Farming: A Case Study in Bangladesh. International Journal of Poultry Science, [online] 4(3), pp.167-176. Available at: $<$ http://freejournal.umm.ac.id/files/file/An\%20Assessment\%20of\%20Vertically\%20Integrated\%20Contract\%20Poul try\%20Farming.pdf> [Accessed 26 Jan. 2021]. 
Begum, I., Alam, M., Rahman, S. and Huylenbroeck, G., 2013. An assessment of the contract farming system in improving market access for smallholder poultry farmers in Bangladesh. [online] . Available at: <https://biblio.ugent.be/publication/4292907/file/4292936.pdf> [Accessed 26 Jan. 2021].

Begum, I.A., Alam, M.J., Buysse, J., Frija, A. and Van Huylenbroeck, G., 2012. Contract farmer and poultry farm efficiency in Bangladesh: a data envelopment analysis. Applied Economics, 44(28), pp.3737-3747.

Begum, M., Sultana, T. and Islam, I.B., 2019. A Critical Overview on Women Entrepreneurship through Poultry farming in Bangladesh. Journal of Emerging Technologies and Innovative Research (JETIR), [online] 6(6). Available at: <https://www.researchgate.net/profile/Ikra_Islam3/publication/344776172_Issue_6_wwwjetirorg_ISSN2349-5162_Paper_id/links/5f8f298b458515b7cf90d8a1/Issue-6-wwwjetirorg-ISSN-2349-5162-Paperid.pdf> [Accessed 26 Jan. 2021].

Begum, I.A. 2008. Prospects and potentialities of vertically integrated contract farming in Bangladesh. Department of Agricultural Development Economics, Hokkaido University, Japan. (unpublished Ph.D. thesis)

Birthal, P.S., P.K. Joshi, and A. Gulati (2005). Vertical coordination in high value commodities: implications for the smallholders. MTID Discussion Paper No. 85. Washington, DC: IFPRI.

Bijman, J., 2008. Contract farming in developing countries: an overview. [online] . Available at: <https://library.wur.nl/WebQuery/wurpubs/fulltext/1763>.

Bridger, J.C. and Luloff, A.E., 1999. Toward an interactional approach to sustainable community development. Journal of Rural Studies, 15(4), pp.377-387.

Catelo, M. A. O., M. A. Dorado, and E. Agbisit, Jr. (2001). Backyard and Commercial Piggeries in the Philippines: Environmental Consequences and Pollution Control Options. EEPSEA Research Report No. 2001-RR6.

Catelo, M.A.O. (2002). "Issues and Policy Options for Addressing Environmental and Human Health Risks Associated with Growth in Small- and Large-Scale Swine and Poultry Production in the Philippines. Livestock Industrialization Project: Phase I.

Catelo, M. O. And A. Costales (2008), “Contract Farming and Other Market Institutions as Mechanisms for Integrating Smallholder Livestock Producers in the Growth and Development of the Livestock Sector in Developing Countries", PPLPI Working Paper, No 45.

Chowdhury, A.M.R. and Bhuiya, A., 2004. The wider impacts of BRAC poverty alleviation programme in Bangladesh. Journal of International Development, 16(3), pp.369-386.

Costales, A.C. 1996. "Food Security and Sustainable Development: Livestock and Feeds." Paper presented at the PAEDA $40^{\text {th }}$ Annual Convention: Philippine Agriculture for Food Security and Sustainable Agriculture, Philippine Agricultural Economics and Development Association (PAEDA) 24 January, Manila, Philippines.

Costales, A.C. 2000. "Pressing Issues for Smallholder Livestock Development in the Context of Overall National Livestock Sector Development in the Philippines." Paper presented at the IFPRI-ILRI Workshop 
on Scale Economies and Smallholder Livestock Production in Developing Countries: Technology, Trade and Policy Issues, International Livestock Research Institute, Addis Ababa, Ethiopia, 25-28 May 2000.

Costales, A.C. 2001. "Livestock to 2020, the Next Food Revolution - Implications to Southeast Asia: The Case of the Philippines". Paper presented at the international workshop on: "Sustainable Animal Production and Food Supply to 2020", School of Veterinary Medicine, Hannover, Federal Republic of Germany, 9-10 August 2000.

Costales, C. and C. Delgado. 2002. "A Synthesis of Changes Impacting on Participation of Smallholders in the Growing Meat Market in the Philippines" Livestock Industrialization, Trade and Social-HealthEnvironment Impacts in The Philippines. Research Report, Phase I.

Dannson, A., et al. (2004). Strengthening farm-agribusiness linkages in Africa. Summary results of five country studies in Ghana, Nigeria, Kenya, Uganda and South Africa. AGSF Occasional Paper 6. Rome, FAO.

Da Silva, C.A. (2005), "The Growing Role of Contract Farming in Agri-food Systems Development: Drivers, Theory and Practice", FAO, Rome.

DLS, 2008. Livestock Economy at a Glance, DLS Table 1. Livestock population of Bangladesh (in lakh number) Livestock Species. [online] . Available at:

<http://dls.portal.gov.bd/sites/default/files/files/dls.portal.gov.bd/page/ee5f4621_fa3a_40ac_8bd9_898fb8 ee4700/Livestock\%20Economy\%20at\%20a\%20glance\%20\%20\%282017-2018\%29.pdf> [Accessed 24 Jan. 2021].

Dolberg, F., 2003. A Review of Household Poultry Production as a Tool in Poverty Reduction with Focus on Bangladesh and India. AgEcon Search. [online] Available at:

<https://ageconsearch.umn.edu/record/23762/> [Accessed 26 Jan. 2021].

Eaton, C. and Shepherd, A.W., 2001. Contract farming - Partnerships for growth. [online] www.fao.org. Available at: <http://www.fao.org/3/y0937e/y0937e02.htm\#P13_7206>.

Ferdous, Z., Zulfiqar, F., Datta, A., Hasan, A.K. and Sarker, A., 2020. Potential and challenges of organic agriculture in Bangladesh: a review. Journal of Crop Improvement, pp.1-24.

Gatto, M., Wollni, M., Asnawi, R. and Qaim, M., 2017. Oil Palm Boom, Contract Farming, and Rural Economic Development: Village-Level Evidence from Indonesia. World Development, 95, pp.127-140.

Glover, D.J. and K. Kusterer (1990). Small farmers, big business: contract farming and rural development. Houndsmills/London: Macmillan

Glover, D.J. (1987). "Increasing the benefits to smallholders from contract farming: Problems for farmers' organizations and policy makers." World Development 15(4): 441-448.

Glover, D. J. (1986). `Agrarian Reform and Agro-Industry in Honduras', Canadian Journal of Development Studies, (1986).

Glover, D.J. (1984). "Contract farming and smallholder outgrower schemes in less-developed countries." World Development 12(11-12): 1143-1157.

Gregory, S. and S, F., Maria, 2016. Identity, household work, and subjective well-being among rural women in Bangladesh. [online] Google Books. Intl Food Policy Res Inst. Available at:

$<$ https://books.google.com.bd/books?hl=en\&lr=\&id=6nO3DQAAQBAJ\&oi=fnd\&pg=PR5\&dq=contract 
+farming+bangladesh+women\&ots=n0hHbidqjZ\&sig=7jJS7iasL_PLYNhM9W3ud9vKkRA\&redir_esc $=$ $\mathrm{y} \# \mathrm{v}=$ onepage $\& \mathrm{q}=$ contract $\% 20$ farming\%20bangladesh\%20women $\& \mathrm{f}=$ false $>$ [Accessed 27 Jan. 2021].

Griggs, D.J., Nilsson, M., Stevance, A. and McCollum, D., 2017. A guide to SDG interactions: from science to implementation. International Council for Science, Paris. [online] Available at:

<https://council.science/wp-content/uploads/2017/05/SDGs-Guide-to-Interactions.pdf> [Accessed 26 Jan. 2021].

Guo, H., R.W. Jolly, and J. Zhu (2005). Contract Farming in China: Supply Chain or Ball and Chain? Paper presented at the 15th Annual World Food \& Agribusiness Symposium, IAMA, Chicago.

Hamilton, N.D. (2008), “Agricultural Contracting: A U.S. Perspective and Issues for India to Consider", in A. Gulat, P.K. Joshi and M. Landes (eds.), Contract Farming in India:

A Resource Book.

Haque, M., Zaman, M.U., Rahman, M. and Alam, Q., 2012. Profitability of Hybrid Maize (Zea mays L.) Seed Production Under Contract Farming in Bangladesh: A Farm Level Study. Bangladesh Journal of Agricultural Research, 37(2), pp.327-334.

Hossain, S. T. (2012). "Organic Farming in Populated Area: Bangladesh - An Example of Case Study." In Organic Farming in Populated Area: Bangladesh - An Example of Case Study , 105-113.

Hoque, M. N. 2012. Eco-friendly and Organic Farming in Bangladesh - International Classification and Local Practice. GEB-IDN/8778 . Germany: Institute of Rural Sociology and Extension, University of Giessen.

Hussain, A.G., Rouf, A.S.S., Shimul, S.N., Nargis, N., Kessaram, T.M., Huq, S.M., Kaur, J., Shiekh, M.K.A. and Drope, J., 2020. The Economic Cost of Tobacco Farming in Bangladesh. International Journal of Environmental Research and Public Health, 17(24), p.9447.

Islam, M.D.I., Rahman, A., Sarker, M.N.I., Sarker, M.S. and Jianchao, L., 2020. Factors Influencing Rice Farmers' Risk Attitudes and Perceptions in Bangladesh amid Environmental and Climatic Issues. Polish Journal of Environmental Studies, 30(1), pp.177-187.

Islam, S M F and Jabbar, M A (2005). Smallholder poultry model for poverty alleviation in Bangladesh: a review of evidence on impact. Livestock Research for Rural Development. Volume 17, Article \#112. Retrieved January 26, 2021, from http://www.lrrd.org/lrrd17/10/fakh17112.htm

Jabbar, M.A., Rahman, M.H., Talukder, R.K. and Raha, S.K., 2007. Alternative institutional arrangements for contract farming in poultry production in Bangladesh and their impacts on equity. [online] Google Books. ILRI (aka ILCA and ILRAD). Available at:

<https://books.google.com.bd/books?hl=en\&lr=\&id=x1 gunJXfvgEC\&oi=fnd\&pg=PR5\&dq=CONTRAC T+FARMING+in+poultry+bangladesh\&ots=GLnJ6_7nTM\&sig=Y9sC8pG_AWCZ7pXjq6IRvcKHjb4\& redir_esc $=\mathrm{y} \# \mathrm{v}=$ onepage $\& \mathrm{q}=\mathrm{CONTRACT} \% 20 \mathrm{FARMING} \% 20 \mathrm{in} \% 20$ poultry $\% 20$ bangladesh $\& \mathrm{f}=$ false $>$ [Accessed 26 Jan. 2021].

Jensen, H. A. (1999) Paradigm and visions: network for poultry production and health in developing countries, in Poultry As a Tool in Poverty Eradication and Promotion of Gender Equality (Eds) F. Dolberg and P. H. Petersen, Tune Landboskole, Denmark, pp. 31-8.

Key, N. and Runsten, D., 1999. Contract Farming, Smallholders, and Rural Development in Latin America: The Organization of Agroprocessing Firms and the Scale of Outgrower Production. World Development, 27(2), pp.381-401. 
Khairul, I. M., Forhad, M. and Alam, M., 2014. Challenges and Prospects of Poultry Industry in Bangladesh. Online), [online] 6(7). Available at: 〈https://core.ac.uk/download/pdf/234625329.pdf> [Accessed 26 Jan. 2021].

Larson, D.F. and World Bank. Policy Research Dissemination Center, 1996. Indonesia's palm oil subsector. Washington: The World Bank.

Little, P.D. and M.J. Watts (1994). Living under contract: contract farming and agrarian transformation in Sub-Saharan Africa. Madison [etc.], University of Wisconsin Press.

Martinez, S.W. and A. Reed (1996). From Farmers to Consumers; Vertical Coordination in the Food Industry. Agriculture Information Bulletin. Washington, DC, ERS/USDA.

Masakure, O. and S. Henson (2005). "Why do small-scale producers choose to produce under contract? Lessons from non-traditional vegetable exports from Zimbabwe." World Development 33(10): 1721 1733.

Meemken, E.-M. and Bellemare, M.F., 2020. Smallholder farmers and contract farming in developing countries. Proceedings of the National Academy of Sciences, [online] 117(1), pp.259-264. Available at: <https://www.pnas.org/content/117/1/259> [Accessed 5 Aug. 2020].

Mendola, M., 2007. Agricultural technology adoption and poverty reduction: A propensity-score matching analysis for rural Bangladesh. Food Policy, [online] 32(3), pp.372-393. Available at: <https://www.sciencedirect.com/science/article/pii/S0306919206000790?casa_token=FvruXSu4MpkAA AAA:MS5qMn5Guno2NtF8NAxIqI76p_g2gW_G5jYOJ8RbLE_kKjGb64gcbTDxOuQCRzD1ZeY_qBAzv4> [Accessed 27 Jan. 2021].

Mighell, R.L. And L.A. Jones (1963), "Vertical Coordination in Agriculture”, U.S. Department of Agriculture, Economic Research Service, Agricultural Economic Report No. 19, February

Minot, N.W. (1986). Contract Farming and its effects on small farmers in less developed countries. MSU International Development Papers. East Lansing, MI, Michigan State University, Department of Agricultural Economics.

Minot, N. (2007). Contract Farming in Developing Countries: Patterns, Impact, and Policy Implications. Case Study \#6-3 of the Program: "Food Policy for Developing Countries: The Role of Government in the Global Food System". Ithaca: Cornell University, New York http://cip.cornell.edu/DPubS? service=UI\&version=1.0\&verb=Display\&handle=dns.gfs\&collection $=$

Mou, N.H., 2012. Profitability of Flower Production and Marketing System of Bangladesh. Bangladesh Journal of Agricultural Research, 37(1), pp.77-95.

Perry, B.D., 2002. Investing in Animal Health Research to Alleviate Poverty. [online] Google Books. ILRI (aka ILCA and ILRAD). Available at:

<https://books.google.com.bd/books?hl=en \&lr=\&id=54hL44LMXsYC\&oi=fnd\&pg=PA1\&dq=role+of+li vestock+in+poverty+alleviation+of+bangladesh\&ots $=8$ wTW6nABon\&sig=Xv0Y5c_ODvNHuMiwu45B oabehbk\&redir_esc $=\mathrm{y} \# \mathrm{v}=$ onepage $\& \mathrm{q}=$ role $\% 20 \mathrm{of} \% 20$ livestock $\% 20 \mathrm{in} \% 20$ poverty $\% 20$ alleviation $\% 20 \mathrm{of} \%$ 20bangladesh\&f=false $>$ [Accessed 24 Jan. 2021].

Pomareda, C. (2006). Contract Agriculture: Lessons from experiences in Costa Rica. Santiago de Chile: RIMISP. 
Rahman, K.M.M., Hossain, Md.J. and Rana, M.S., 2020. LIVESTOCK AND POULTRY REARING BY SMALLHOLDER FARMERS IN HAOR AREAS IN BANGLADESH: IMPACT ON FOOD SECURITY AND POVERTY ALLEVIATION: The Bangladesh Journal of Agricultural Economics, [online] 41(1), pp.73-86. Available at: <http://bjae.bau.edu.bd/home/article/view/50>.

Reardon, T. and C.B. Barrett (2000). "Agro industrialization, globalization, and international development. An overview of issues, patterns, and determinants." Agricultural Economics 23: 195-205.

Reardon, T. and J.A. Berdegue (2002). "The Rapid Rise of Supermarkets in Latin America: Challenges and Opportunities for Development." Development Policy Review 20(4): 371-388.

Rogers, M. and Ryan, R., 2001. The Triple Bottom Line for Sustainable Community Development. Local Environment, 6(3), pp.279-289.

Roseland, M., 2000. Sustainable community development: integrating environmental, economic, and social objectives. Progress in Planning, [online] 54(2), pp.73-132. Available at: <http://chs.ubc.ca/lprv/PDF/lprv0073.pdf>.

Roy, R., Chan, N.W. and Rainis, R., (2013). Rice farming sustainability assessment in Bangladesh. Sustainability Science, 9(1), pp.31-44.

Roy, E. P. (1972). Contract Farming and Economic Integration, (Danville, Ill.: The Interstate, 1972).

ROY, E.P. (1963), Contract Farming, The Interstate Printers and Publishers Inc., Danville, Illinois.

Royer, J.S. and R.T. Rogers, Eds. (1998). The industrialization of agriculture. Vertical coordination in the U.S. food system. Aldershot, Ashgate.

Runsten, D. and N. Key (1996). Contract farming in developing countries: theoretical issues and analysis of some Mexican cases. Santiago de Chile, Economic Commission for Latin America and the Caribbean (Report LC/L.989).

Saiful, I., Abu Hayat Md, Devesh, R., Anjani, K., Gaurav, T. and Kumar, J., Pramod, 2019. Dairy contract farming in Bangladesh: Implications for welfare and food safety. [online] Google Books. Intl Food Policy Res Inst. Available at:

<https://books.google.com.bd/books?hl=en\&lr=\&id=UBqWDwAAQBAJ\&oi=fnd\&pg=PR3\&dq=contrac $\mathrm{t}+$ farming+in+bangladesh\&ots=8edXvAdtS9\&sig=0EqDEiESJjeaA8L28-TDr-

jPhz4\&redir_esc $=\mathrm{y} \# \mathrm{v}=$ onepage $\& \mathrm{q}=$ contract $\% 20$ farming\%20in $\% 20$ bangladesh $\& \mathrm{f}=$ false $>$ [Accessed 26 Jan. 2021].

Sarkar, M., Rashid, M. and Sarker, M., 2013. Contract Farming in Tomato Seed Production in Rangpur District of Bangladesh: A Financial Analysis. Progressive Agriculture, 22(1-2), pp.169-179.

Sarma, P. K., 2014. An Agribusiness development approach of beef cattle in selected areas of Bangladesh. Journal of the Bangladesh Agricultural University, [online] 12(2). Available at: <https://ageconsearch.umn.edu/record/211252/> [Accessed 26 Jan. 2021].

Setboonsarng, S., Leung, P. and Cai, J., 2006. Contract Farming and Poverty Reduction: the Case of Organic Rice Contract Farming. [online] CiteSeer. Available at:

<http://citeseerx.ist.psu.edu/viewdoc/summary?doi=10.1.1.577.4876\&rank=5> [Accessed 25 Jan. 2021].

Shaffer, R., Deller, S. and Marcouiller, D., 2006. Rethinking Community Economic Development. Economic Development Quarterly, 20(1), pp.59-74. 
Sheel, S.K. and Sen, B.K., 2013. Poultry Contract Farming in Bangladesh with Special Reference to Aftab Bahumukhi Farm Limited (ABFL). Journal of Business Studies, [online] XXXIV(1). Available at: <https://www.fbs-du.com/news_event/14664804555.pdf> [Accessed 26 Jan. 2021].

Shepherd, A.W. (2005). The implications of supermarket development for horticultural farmers and traditional marketing systems in Asia (revised paper). FAO/AFMA/FAMA Regional Workshop on the Growth of Supermarkets as Retailers of Fresh Produce. Kuala Lumpur.

Smith, J., Sones, K., Grace, D., MacMillan, S., Tarawali, S. and Herrero, M., 2013. Beyond milk, meat, and eggs: Role of livestock in food and nutrition security. Animal Frontiers, [online] 3(1), pp.6-13. Available at: <https://academic.oup.com/af/article/3/1/6/4638645> [Accessed 7 Mar. 2019].

Simmons, P. (2002). Overview of Smallholder Contract Farming in Developing Countries. ESA Working Paper Rome, FAO.

Simmons, P., P. Winters, and I. Patrick (2005). "An analysis of contract farming in East Java, Bali, and Lombok, Indonesia." Agricultural Economics 33(S3): 513-525.

Singh, S. (2002). "Contracting Out Solutions: Political Economy of Contract Farming in the Indian Punjab." World Development 30(9): 1621-1638.

Swinnen, J. And M. Maertens (2007), "Globalization, privatization, and vertical coordination in food value chains in developing and transition countries", Agricultural Economics 37(1), pp.89-102

Tabassum, N. and Kim, C.-W., 2009. A study on the profitability and marketing costs of seed potato farming in Bangladesh. Korean Journal of Food Preservation, [online] 16(4), pp.490-498. Available at: <https://www.koreascience.or.kr/article/JAKO200932056738541.page> [Accessed 26 Jan. 2021].

United Nations, 2010. \#Envision2030 Goal 1: No Poverty | United Nations Enable. [online] Un.org. Available at: <https://www.un.org/development/desa/disabilities/envision2030-goal1.html> [Accessed 27 Jan. 2021].

United States Department of Agriculture (USDA, 2020. THIS REPORT CONTAINS ASSESSMENTS OF COMMODITY AND TRADE ISSUES MADE BY USDA STAFF AND NOT NECESSARILY STATEMENTS OF OFFICIAL U.S. GOVERNMENT POLICY. [online] https://apps.fas.usda.gov/. Available at: $<$ https://apps.fas.usda.gov/newgainapi/api/Report/DownloadReportByFileName?fileName=Grain\%20and \%20Feed\%20Annual_Dhaka_Bangladesh_03-27-2020> [Accessed 27 Jan. 2021].

Upton, M., 2004. The Role of Livestock in Economic Development and Poverty Reduction. [online] ageconsearch.umn.edu. AgEconSearch. Available at: 〈https://ageconsearch.umn.edu/record/23783/> [Accessed 24 Jan. 2021].

Wadud, F., Babu, S.C. and Afrad, S.I., 2015. Private Provision of Extension Through the Contract Farming Approach in Bangladesh. Knowledge Driven Development, pp.201-218.

Zamil, Md.F. and Cadilhon, J.-J., 2009. Developing small production and marketing enterprises: mushroom contract farming in Bangladesh. Development in Practice, 19(7), pp.923-932. 